\title{
Aikuiskoulutuksen hallinnon uudistustarpeet
}

Aikuiskoulutusneuvosto asetti loppukeväästä 1988 jaoston, jonka tehtävänä oli valmistella suunnitelma aikuiskoulutuksen hallinnon kehittämiseksi ja hajauttamiseksi. Tämä aluehallinnon jaosto sai työnsä valmiiksi vuoden 1989 alussa.

\section{Aluehallinnon jaoston työskentely}

Aluehallinnon jaoston puheenjohtajana toimi vt. opintojohtaja Tapani Ranki sekä muina jäseninä projektisuunnittelija Raimo Rissanen, rehtori Matti Väisänen, apulaisosastopäällikkö Olavi Alkio ja ammattikasvatustarkastaja Timo Lähdesmäki. Sihteerinä toimi tämän artikkelin kirjoittaja.

Jaoston työskentely alkoi käytännössä vasta alkusyksystä 1988, jolloin jaosto valitsi itselleen sihteerin.

Lähes ensi töikseen jaosto törmäsi toimeksiannon laajuuteen: sekä toimintojen että asiakokonaisuuksien moninaisuuteen. Toisaalta aikaa oli käytettävissä vain muutama kuukausi, sillä määräajaksi oli asetettu vuoden 1989 al$\mathrm{ku}$.

Toimintokohtaisesti tarkastelun ulkopuolelle jätettiin sellainen aikuiskoulutus, joka ei ole valtion rahoituksen piirissä. Lisäksi ulkopuolelle jätettiin vielä mm. korkeakoulujen antama täydennyskoulutus, kesäyliopistot sekä muiden kuin opetusministeriön alainen ammatillinen koulutus. Tehtyjen rajausten jälkeen jäljelle jäivät seuraavat toiminnot:

- ammatilliset oppilaitokset,

- ammatilliset erikoisoppilaitokset,

- ammatilliset kurssikeskukset,

- iltalukiot ja lukioiden iltalinjat,

- kansalais- ja työväenopistot,

- kansanopistot,

- neuvontajärjestöt,

— opintokeskukset ja

— oppisopimuskoulutus.
Eri asiakokonaisuuksien osalta jaosto joutui myös tekemään rajauksia. Jaosto ryhmitteli tarkastelemansa asiakokonaisuudet seuraavasti:

— määrällinen säätely,

- käyttökustannusten valtionrahoitusperusteet,

— opiskelijoiden kotikuntien käyttökustannusvastuu,

- opetusryhmien muodostaminen ja

— henkilöstöjärjestelyt

Jaosto käytti pääjaotteluna asiakokonaisuuksia siten, että kunkin asiakokonaisuuden osalta tarkasteltiin ensin nykytilannetta toimintokohtaisesti. Toiseksi esitettiin kehittämistarpeet ja kolmanneksi varsinaiset toimenpideehdotukset. Sekä kehittämistarpeiden että toimenpide-ehdotusten osalta kannanotot esitettiin yleisesti puuttumatta yksittäisiin toimintoihin. Tämä ei kuitenkaan johtanut siihen, että kannanotot olisivat jääneet pintapuolisiksi.

Vaikka jaoston jäsenet ja sihteeri olivat taustoiltaan varsin erilaisia, yleistoteamuksena jaoston voi katsoa työskennelleen erittäin hyvässä yhteisymmämyksessä. Toisaalta jaoston kokoonpanon monipuolisuus mahdollisti varsin laajan ja yksityiskohtaisen tarkastelun aikuiskoulutuksen hallinnon kehittämiseksi.

\section{Toimenpide-ehdotukset}

Yleiskannanottona aluehallinnon jaosto päätyi siihen, että useimmat sen esille ottamat asiakokonaisuudet edellyttäisivät laaja-alaista ja perusteellista selvitystä. Lisäksi jaoston toimenpide-ehdotukset edellyttävät useita lainmuutoksia. Jaosto asetti myös kyseenalaiseksi aikuiskoulutuksen nykyisen toimintokeskeisyyden. 
Asiakokonaisuuksittain merkittävimmät jaoston kannanotoista liittyivät määrälliseen säätelyyn ja käyttökustannusten valtionrahoitusperusteisiin. Näillä kahdella asiakokonaisuudella on myös selvä keskinäinen yhteys. Muiden asiakokonaisuuksien osalta toimenpide-ehdotukset koskivat yleensä toimintokohtaisten erojen poistamista ja päätösvallan siirtoa alaspäin, erityisesti koulutuksen järjestäjälle.

Määrällisessä säätelyssä jaosto esitti toimenpiteet kahdessa ryhmässä: kiireelliset toimenpiteet ja pitkän aikavälin toimenpiteet.

Määrällisen säätelyn kiireellisinä toimenpide-ehdotuksina jaosto esitti mm.:

- eri toimintoja koskevan yhtenäisen ylläpitojärjestelmän luominen,

- määrällisen säätelyn lopettaminen ja osittain keventäminen,

- omaehtoisen ammatillisen aikuiskoulutuksen järjestämisessä ammatillisen koulutuksen kuntainliitoille muita koulutuksen järjestäjiä laajempi itsenäinen toimivalta ja

- muiden kuin kuntainliittojen järjestämän omaehtoisen ammatillisen peruskoulutuksen ja jatkolinjojen yhteensovitus alueittain lääninhallituksen tehtävä.
Määrällisen säätelyn pitkän aikavälin toimenpide-ehdotuksina jaosto esitti mm.:

- toimintosidonnaisuudesta luopuminen pääosin,

- aikuiskoulutuksen organisointi kunnassa kunnan itsenä päätettäväksi ja toimintokohtainen hallinto yleisesti ylläpitäjän päätettäväksi,

- opintokeskusten toiminnan yhteensovitus valtakunnallisesti,

- omaehtoisen ammatillisen peruskoulutuksen ja jatkolinjojen alueellinen yhteensovitus alueellaan maakunnalliselle kuntainliitolle, mikäli tällaisiin kuntainliittoihin päädytään nuorisoikäisten ammatillisen koulutuksen yhteensovittamisessa.

Käyttökustannusten valtionrahoitusperusteiden osalta merkittävimpinä toimenpide-ehdotuksina voi pitää lakisääteisen valtionosuusjärjestlemän luomista koko aikuiskoulutukselle sekä todellisten kustannusten ja suoritepohjaisten perusteiden sekajärjestelmän ottamista valtionosuuden määräytymisperusteiksi. Valtionosuuden määrään liittyen jaosto esitti, että valtionosuuden tulee määräytyä koulutustehtävän eikä toiminnon mukaan. 